\title{
Streptomyces oryzae sp. nov., an endophytic actinomycete isolated from stems of rice plant
}

\author{
Ratchanee Mingma ${ }^{1,2}$, Kannika Duangmal ${ }^{1,2}$, Arinthip Thamchaipenet ${ }^{2,3}$, Savitr Trakulnaleamsai ${ }^{1,2}$, \\ Atsuko Matsumoto ${ }^{4}$ and Yoko Takahashi ${ }^{4}$
}

An actinomycete strain $\mathrm{S} 16-07^{\top}$, isolated from surface-sterilized stems of rice plant (Oryza sativa L.), was characterized using a polyphasic approach. Phylogenetic analysis of 16S rRNA gene sequences indicated affiliation of the strain belonged to the genus Streptomyces. The highest levels of sequence similarity were found with Streptomyces smyrnaeus SM3501 ${ }^{\top}(97.7 \%$ similarity), S. abikoensis NBRC $13860^{\top}$ (97.6\% similarity) and S. thermocarboxydovorans NBRC $16324^{\top}(97.5 \%$ similarity). The cell wall of strain S16-07 ${ }^{\top}$ contained LL-diaminopimelic acid. The predominant menaquinones were MK-9( $\left.\mathrm{H}_{6}\right)$ and $\mathrm{MK}-9\left(\mathrm{H}_{8}\right)$. Phospholipids detected were phosphatidylethanolamine, phosphatidylglycerol, diphosphatidylglycerol, hydroxyphosphatidylethanolamine, hydroxy-phosphatidylmonomethylethanolamine and phosphatidylinositol mannosides. The major cellular fatty acids were ai- $\mathrm{C}_{15: 0}, \mathrm{i}-\mathrm{C}_{16: 0}$ and ai- $\mathrm{C}_{17: 0}$. The $\mathrm{G}+\mathrm{C}$ content of strain $\mathrm{S} 16-07^{\top}$ was $70.4 \mathrm{~mol} \%$. On the basis of the phylogeny of the isolate and its differences from the most closely related species, the isolate $\mathrm{S} 16-07^{\top}$ represents a novel species for which the name $S$. oryzae sp. nov. is proposed. The type strain is $\mathrm{S} 16-07^{\top}\left(=\mathrm{BCC} 60400^{\top}=\mathrm{NBRC} 109761^{\top}\right)$. The Journal of Antibiotics (2015) 68, 368-372; doi:10.1038/ja.2014.166; published online 14 January 2015

\section{INTRODUCTION}

The genus Streptomyces was first proposed by Waksman and Henrici $^{1}$ and was classified in the family Streptomycetaceae, order Actinobacteria. $^{2}$ This genus currently contains more than 650 recognized species with validly published names. ${ }^{3}$ Members of the genus Streptomyces are aerobic, Gram-stain-positive, chemoorganotrophic actinomycetes and form an extensively branched substrate mycelium with rarely fragment. The aerial mycelium forms chains of three to many spores at maturity. Chemotaxonomic characteristics show lack of mycolic acids, type I cell wall containing LL-diaminopimelic acid but no characteristic sugars and contain major amounts of saturated, iso- and anteiso-fatty acids. The major menaquinone is either hexa- or octahydrogenated with nine isoprene units. The phospholipid patterns typically contain diphosphatidylglycerol, phosphatidylethanolamine, phosphatidylinositol and phosphatidylinositol mannosides. The DNA G+C content is in the range 66-78 mol\% ${ }^{4}$ During study the diversity of endophytic actinomycetes from stems and roots of rice plant, an actinomycete designated S16-0 $07^{\mathrm{T}}$, was isolated and assigned to the genus Streptomyces. The aim of the present study was to determine the taxonomic status of the strain S16- $07^{\mathrm{T}}$ using genotypic and phenotypic characteristics. The resultant data indicated that the organism should be classified as a novel species of Streptomyces, for which the name Streptomyces oryzae sp. nov. is proposed.

\section{MATERIALS AND METHODS}

Strain $S 16-07^{\mathrm{T}}$ was isolated from surface-sterilized stems of rice plant (O. sativa L.) collected from Petchaburi province, Thailand. Stem samples were surface-sterilized according to the method as described by Mingma et al. ${ }^{5}$ and crushed with sterile glass rod in 1/4 strength Ringer's solution. Crushed plant tissue suspensions were spread on starch casein $\operatorname{agar}^{6}$ supplemented with ketoconazole $\left(100 \mu \mathrm{g} \mathrm{ml}^{-1}\right)$, nystatin $\left(50 \mu \mathrm{g} \mathrm{ml}^{-1}\right)$ and nalidixic acid $\left(25 \mu \mathrm{g} \mathrm{ml}^{-1}\right)$ and incubated at $28^{\circ} \mathrm{C}$ for 21 days. Pure colony of strain S16-07 was kept on glucose yeast extract agar (containing glucose $1.0 \%(\mathrm{w} / \mathrm{v})$, yeast extract $1.0 \%(\mathrm{w} / \mathrm{v})$ and agar $1.5 \%(\mathrm{w} / \mathrm{v}))$. Spore and cell suspensions were stored as lyophilized ampules at $4{ }^{\circ} \mathrm{C}$ and in $20 \%(\mathrm{v} / \mathrm{v})$ glycerol at $-20^{\circ} \mathrm{C}$.

Strain $\mathrm{S} 16-07^{\mathrm{T}}$ and the type strains of S. abikoensis NBRC $13860^{7}$, S. thermocarboxydovorans NBRC $16324^{8}$ and S. lilacinus ISP $5254^{9}$ were studied together for biochemical, cultural and physiological characteristics. S. smyrnaeus $\mathrm{SM} 3501^{\mathrm{T}}$ has recently been described by Tatar et al. ${ }^{10}$ and showed the highest similarity with the strain $516-07^{\mathrm{T}}$. At this time of writing, S. smyrnaeus $\mathrm{SM} 3501^{\mathrm{T}}$ was just published in International Journal of Systematic and Evolutionary Microbiology. Therefore, the cultural and physiological properties of S. smyrnaeus SM3501 ${ }^{\mathrm{T}}$ were obtained from Tatar et al. ${ }^{10}$ for comparison purpose. Morphological observations of spores and mycelia of strain $S 16-07^{\mathrm{T}}$ were examined after incubation at $27^{\circ} \mathrm{C}$ for 14 days by light microscope and scanning electron microscope (JEOL-JSM 5600 LV, Tokyo, Japan). Cultural characteristics were determined from the growth on ISP (International Streptomyces Project) media ${ }^{11} 2,3,4$ and 5, potato dextrose agar (PDA), Czapek's agar and nutrient agar..$^{12}$ The characteristics were recorded after 14 days of incubation at $27^{\circ} \mathrm{C}$. The Color Harmony Manual Charts ${ }^{13}$ were used to determine color designations. The utilization of carbohydrates as sole carbon

${ }^{1}$ Department of Microbiology, Faculty of Science, Kasetsart University, Bangkok, Thailand; ${ }^{2}$ Center for Advanced Studies in Tropical Natural Resources, NRU-KU, Kasetsart University, Bangkok, Thailand; ${ }^{3}$ Department of Genetics, Faculty of Science, Kasetsart University, Bangkok, Thailand and ${ }^{4}$ Kitasato Institute for Life Sciences, Kitasato University, Tokyo, Japan

Correspondence: Dr K Duangmal, Department of Microbiology, Faculty of Science, Kasetsart University, Chatuchak, Bangkok 10900, Thailand.

E-mail: fscikkd@ku.ac.th

Received 9 August 2014; revised 1 November 2014; accepted 20 November 2014; published online 14 January 2015 

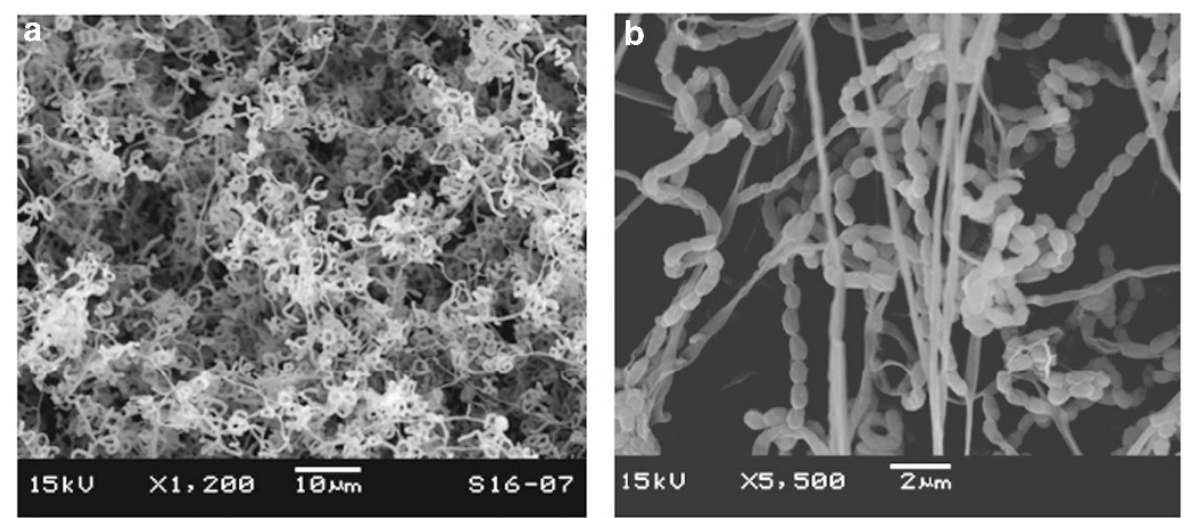

Figure 1 Scanning electron micrographs of the retinaculum apertum (RA) spore chains and smooth-surfaced spores of Streptomyces oryzae S16-07 ${ }^{\top}$ after cultivation on ISP medium 4 (a) and ISP medium 5 (b) at $27^{\circ} \mathrm{C}$ for 2 weeks.

Table 1 Growth and cultural characteristics of the strain $\mathrm{S} 16-07^{\top}$

\begin{tabular}{|c|c|c|c|c|}
\hline Agar media & Growth & $\begin{array}{l}\text { Aerial mycelium } \\
\text { colour; abundance }\end{array}$ & $\begin{array}{c}\text { Substrate } \\
\text { mycelium color }\end{array}$ & $\begin{array}{c}\text { Soluble } \\
\text { pigment color }\end{array}$ \\
\hline ISP medium 2 & Good & White; moderate & Yellow & Yellow \\
\hline ISP medium 3 & Moderate & White; moderate & Pale yellow & Pale yellow \\
\hline ISP medium 4 & Moderate & White; moderate & Pale yellow & Pale yellow \\
\hline ISP medium 5 & Good & White; moderate & Pale yellow & None \\
\hline Nutrient agar & Moderate & White; sparse & Pale yellow & None \\
\hline $\begin{array}{l}\text { Potato } \\
\text { dextrose agar }\end{array}$ & Moderate & White; sparse & Pale yellow & Pale yellow \\
\hline Czapek's agar & Good & White; sparse & White & None \\
\hline
\end{tabular}

source was investigated on ISP medium $9 .{ }^{11}$ Tolerance of sodium chloride $(0,1$, $2,3,4,5,10$ and $15 \%,(\mathrm{w} / \mathrm{v}))$ was tested using ISP medium 2 . To determine the optimal temperature and $\mathrm{pH}$ for growth, strain $\mathrm{S} 16-07^{\mathrm{T}}$ was incubated for 14 days on ISP medium 2 at temperatures of $5-50^{\circ} \mathrm{C}$, and at $\mathrm{pHs}$ ranging from 3.0 to 11.0 (at intervals of $1.0 \mathrm{pH}$ unit). Enzyme activity profiles were carried out using the API ZYM (bioMérieux) test kits. ${ }^{14}$ Melanin pigment was examined on ISP medium 6 and ISP medium $7 .{ }^{11}$ The production of hydrogen sulfide was detected using lead acetate strips. Hydrolysis of adenine, casein, cellulose, chitin, guanine, hypoxanthine, tyrosine, starch, xanthine and urea was examined by following the methods of Gordon and $\mathrm{Mihm}^{15}$ and Gordon et al. ${ }^{16}$

Cells for the chemotaxonomic studies were obtained after incubation of the strain in ISP medium 2 broth at $27^{\circ} \mathrm{C}$ for 2 weeks in shake flasks. The cells were harvested using centrifuged and washed three times with distilled water before freeze-drying. The isomer of diaminopimelic acid was identified using the method of Becker et al. ${ }^{17}$ and Hasegawa et al. ${ }^{18}$ The sugar compositions of whole-cell wall were determined by chromatography as described by Lechevalier and Lechevalier. ${ }^{19}$ The acyl type of the cell wall was analysed by using the method of Uchida and Aida. ${ }^{20}$ Polar lipids were examined using two-dimensional TLC and identified by the method of Minnikin et al. ${ }^{21}$ The presence of mycolic acid was detected by TLC according to the method of Tomiyasu. ${ }^{22}$ Menaquinones were extracted from freeze-dried biomass using the procedure of Collins et $a l^{23}$ and subsequently analyzed by LC/MS (JMS-T100LP, JEOL) with PEGASIL ODS column $(2 \varnothing \times 50 \mathrm{~mm})$ using methanol/2-propanol (7:3). Fatty acid methyl esters were prepared and separated using a previously described by Sasser ${ }^{24}$ and identified using with the MIDI Sherlock Microbial Identification System (Microbial ID; MIDI Version 6.1). The fatty acid analysis was performed at the Faculty of Science, King Mongkut's Institute of Technology Ladkrabang (KMITL), Thailand.

Genomic DNA was extracted as described by Kieser et al. ${ }^{25}$ and used as templates for PCR amplification and sequencing according to the procedure of Mingma et al..$^{5}$ The resultant $16 \mathrm{~S}$ rDNA sequence was aligned with closely related 16S rRNA gene sequence from the EzTaxon-e server (http://eztaxon-e. ezbiocloud.net/). ${ }^{26}$ Multiple sequence alignments were performed using the CLUSTAL W program integrated in the Molecular Evolutionary Genetics Analysis (MEGA) version 5.0. ${ }^{27}$ For phylogenetic analysis, reference strains were chosen according to the highest pairwise similarity among the top 22 BLASTN hits against the EzTaxon-e database. Phylogenetic tree was constructed by the neighbor-joining, ${ }^{28}$ maximum likelihood ${ }^{29}$ and maximum parsimony ${ }^{30}$ methods with the MEGA 5.0 software package. A phylogenetic tree and distance matrix were reconstructed by using the neighbor-joining method and generated using the models by Jukes and Cantor ${ }^{31}$. The topology of the phylogenetic tree was evaluated by the bootstrap resampling method of Felsenstein ${ }^{32}$ with 1000 replicates. Genomic DNA for hybridization was prepared according to the method described by Saito and Miura. ${ }^{33}$ DNA-DNA relatedness was measured fluorometrically using the microplate hybridization method. ${ }^{34}$ The $\mathrm{G}+\mathrm{C}$ content $(\mathrm{mol} \%)$ of the DNA was determined by HPLC according to the method of Tamaoka and Komagata. ${ }^{35}$

\section{RESULTS AND DISCUSSION}

Strain $\mathrm{S} 16-07^{\mathrm{T}}$ produced branched, nonfragmented substrate mycelium. The aerial mycelia harbored spore chains of hooks, open loops or primitive spiral, which belong to retinaculum apertum type of morphology that consisted of 10 or more spores per chain. Spore chain morphology of strain $\mathrm{S} 16-07^{\mathrm{T}}$ was different from other closely related species as follow: S. smyrnaeus $\mathrm{SM} 3501^{\mathrm{T}}$ produced spiral spore chains $;^{10}$ S. abikoensis NBRC $13860^{\mathrm{T}}$ produced straight spore chains; ${ }^{7}$ S. thermocarboxydovorans NBRC $16324^{\mathrm{T}}$ formed spores in long straight to flexuous ${ }^{8}$ and S. lilacinus ISP $5254^{\mathrm{T}}$ produced verticillate spore chain. ${ }^{9}$ The spores of strain $S 16-07^{\mathrm{T}}$ were oval to rod shaped and $0.5 \times 1.0 \mu \mathrm{m}$ in size. Spore surface was smooth (Figure 1). The cultural characteristics of strain $S 16-07^{\mathrm{T}}$ on different kinds of media are presented in Table 1. Strain S16-07 $7^{\mathrm{T}}$ showed good growth on ISP medium 2, ISP medium 5 and Czapek's agar and moderate growth on several media including ISP medium 3, ISP medium 4, nutrient agar and PDA. The substrate mycelium of strain on most media tested was white to pale yellow with whitish aerial spore mass. Pale yellow to yellow diffusible pigment was detected when the strain was cultured on ISP medium 2, ISP medium 3, ISP medium 4 and PDA. Melanin pigment was not observed on both ISP medium 6 and ISP medium 7.

The physiological properties that differentiated strain $\mathrm{S} 16-07^{\mathrm{T}}$ from S. smyrnaeus SM3501 ${ }^{\mathrm{T}}$, S. abikoensis NBRC $13860^{\mathrm{T}}$, S. thermocarboxydovorans NBRC $16324^{\mathrm{T}}$ and S. lilacinus ISP $5254^{\mathrm{T}}$ are shown in Table 2. Strain $S 16-07^{\mathrm{T}}$ utilized adonitol, $\mathrm{D}(-)$ rhamnose, raffinose and sucrose, whereas S. abikoensis NBRC $13860^{\mathrm{T}}$, S. thermocarboxydovorans NBRC $16324^{\mathrm{T}}$ and S. lilacinus ISP $5254^{\mathrm{T}}$ did not. In addition, S16 $-07^{\mathrm{T}}$ could use $\mathrm{L}(+)$ arabinose, $\mathrm{D}(+)$ cellobiose, $\mathrm{D}(+)$ 
Table 2 Comparison of physiological characteristics of strain $\mathrm{S} 16-07^{\top}$ and related species of the genus Streptomyces

\begin{tabular}{|c|c|c|c|c|c|}
\hline Characteristic & 1 & $2^{a}$ & 3 & 4 & 5 \\
\hline \multicolumn{6}{|c|}{ Assimilation of sole carbon sources $(1.0 \%, \mathrm{w} / \mathrm{V})$} \\
\hline Adonitol & + & + & - & - & - \\
\hline $\mathrm{L}(+)$ Arabinose & + & + & - & + & - \\
\hline $\mathrm{D}(+)$ Cellobiose & + & + & - & ++ & - \\
\hline$D(-)$ Fructose & ++ & + & + & + & - \\
\hline $\mathrm{D}(+)$ Galactose & + & + & - & ++ & - \\
\hline Beta-lactose & ++ & + & - & ++ & - \\
\hline $\mathrm{D}(-)$ Mannitol & ++ & + & - & ++ & - \\
\hline $\mathrm{D}(-)$ Rhamnose & + & ND & - & - & - \\
\hline Raffinose & + & ND & - & - & - \\
\hline$D(-)$ Sorbitol & - & + & - & - & - \\
\hline Sucrose & ++ & + & - & - & - \\
\hline Xylitol & - & + & - & - & - \\
\hline Xylose & + & + & - & + & - \\
\hline \multicolumn{6}{|l|}{ Degradation of } \\
\hline Adenine & - & + & - & + & - \\
\hline Casein & + & - & - & + & + \\
\hline Hypoxanthine & + & ND & - & + & + \\
\hline Tyrosine & + & ND & + & - & + \\
\hline Urea & + & - & - & - & - \\
\hline Growth pH & $6.0-9.0$ & $4.0-12.0$ & $5.0-8.0$ & $6.0-11.0$ & $6.0-8.0$ \\
\hline \multicolumn{6}{|c|}{ Growth in the presence of } \\
\hline $10 \% \mathrm{NaCl}$ & + & + & - & - & - \\
\hline $15 \% \mathrm{NaCl}$ & - & + & - & - & - \\
\hline
\end{tabular}

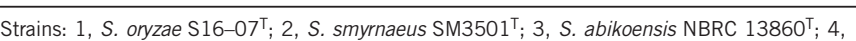
$S$. thermocarboxydovorans NBRC $16324^{\top} ; 5$, S. lilacinus ISP $5254^{\top}$. All data were generated in the present study unless otherwise indicated. ++ strongly positive; + , positive; - , negative;

ND, not determined.

aData were taken from Tatar et al. ${ }^{10}$ galactose, beta-lactose and $\mathrm{D}(-)$ mannitol, a property which was negative in S. abikoensis NBRC $13860^{\mathrm{T}}$ and S. lilacinus ISP $5254^{\mathrm{T}}$. S. smyrnaeus $\mathrm{SM} 3501^{\mathrm{T}}$ utilized $\mathrm{D}(-)$ sorbitol and xylitol as the sole carbon source but strain $S 16-07^{\mathrm{T}}$ could not. Strain $\mathrm{S} 16-07^{\mathrm{T}}$ could utilize urea and degrade casein, whereas S. smyrnaeus SM3501 ${ }^{\mathrm{T}}$ and S. abikoensis NBRC $13860^{\mathrm{T}}$ could not. Strain $\mathrm{S} 16-07^{\mathrm{T}}$ could tolerate $\mathrm{NaCl}$ at concentration up to $10 \%$, whereas S. smyrnaeus $\mathrm{SM} 3501^{\mathrm{T}}$ could tolerate up to $20 \%$. On the other hand, S. abikoensis NBRC $13860^{\mathrm{T}}$, S. thermocarboxydovorans NBRC $16324^{\mathrm{T}}$ and S. lilacinus ISP $5254^{\mathrm{T}}$ could tolerate only $5 \% \mathrm{NaCl}$. Strain $\mathrm{S} 16-07^{\mathrm{T}}$ utilized fructose, glycerol, myo-inositol, maltose, trehalose and xylose as the sole carbon source but not melibiose, $\mathrm{D}(-)$ sorbitol and sorbose. Alkaline phosphatase, leucine aminopeptidase, acid phosphatase, phosphoamidase, $\alpha$-glucosidase and glucosaminidase were detected with the API ZYM enzyme assay, but not chymotrypsin, cystine aminopeptidase, esterase (C4), esterase lipase (C8), $\alpha$-fucosidase, $\alpha$-galactosidase, $\beta$-galactosidase, $\beta$-glucosidase, $\beta$-glucuronidase, lipase (C14), $\alpha$-mannosidase, trypsin and valine aminopeptidase. The temperature range for growth of strain $\mathrm{S} 16-07^{\mathrm{T}}$ was $14-43^{\circ} \mathrm{C}$, with the optimum temperature $23-32^{\circ} \mathrm{C}$. The $\mathrm{pH}$ range for growth was $6.0-9.0$.

An analysis of whole-cell hydrolysates showed that the strain S16- $07^{\mathrm{T}}$ contained LL-diaminopimelic acid, which was characteristic for the genus Streptomyces. The whole-cell sugars were detected as galactose, glucose and ribose. The muramic acid in the peptidoglycan was $\mathrm{N}$-acetylated. Polar lipids were of type II, according to the phospholipid classification of Lechevalier et al. ${ }^{36}$ and included phosphatidylethanolamine, phosphatidylglycerol, diphosphatidylglycerol, hydroxy-phosphatidylethanolamine, hydroxy-phosphatidylmonomethylethanolamine and phosphatidylinositol mannosides (Supplementary Figure $\mathrm{S} 1$ ). The major menaquinones found were MK-9 $\left(\mathrm{H}_{6}\right)(49.6 \%)$ and MK-9 $\left(\mathrm{H}_{8}\right)(41.6 \%)$, with minor amounts of $\mathrm{MK}-10\left(\mathrm{H}_{6}\right)(4.9 \%)$ and $\mathrm{MK}-10\left(\mathrm{H}_{8}\right)(3.9 \%)$. The fatty acids were ai- $\mathrm{C}_{15: 0}(29.4 \%)$, i- $\mathrm{C}_{16: 0}(28.3 \%)$, ai- $\mathrm{C}_{17: 0}(17.9 \%)$, i- $\mathrm{C}_{15: 0}(3.8 \%)$,

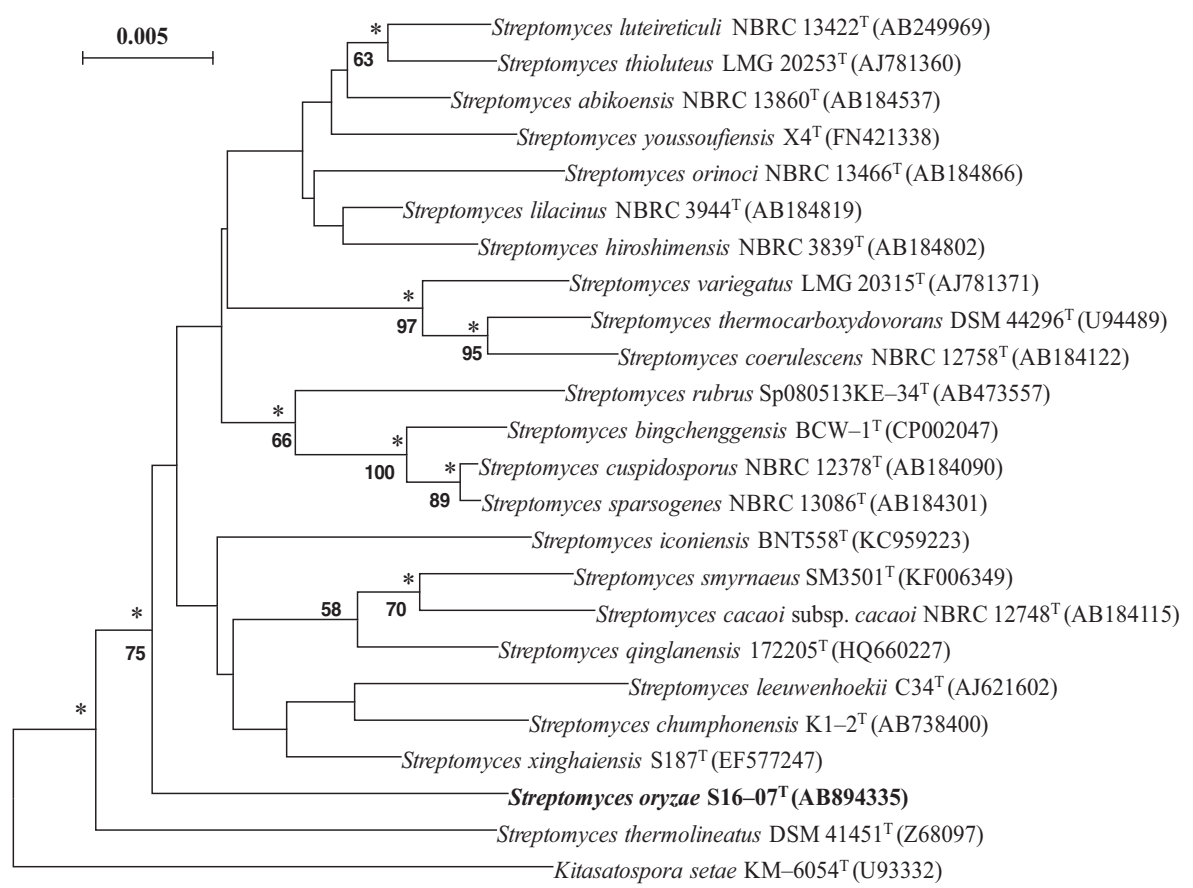

Figure 2 Neighbor-joining phylogenetic tree, based on nearly complete $16 \mathrm{~S}$ rRNA gene sequences, showing the relationships between strain S16-07 ${ }^{\top}$ and strains of related species of the genus Streptomyces. Numbers at nodes are bootstrap values based on 1000 resamplings (only values $>50 \%$ are indicated). Asterisks indicate that the clades are also recovered in maximum-likelihood and maximum-parsimony trees. Bar, $0.005 \%$ sequence divergence. 
i- $\mathrm{C}_{14: 0}(3.8 \%), \mathrm{C}_{16: 0}(3.2 \%), \mathrm{i}-\mathrm{H}-\mathrm{C}_{16: 1}(3.1 \%)$, ai- $\mathrm{C}_{17: 1} w 9 \mathrm{c}(2.7 \%)$, i-C 17:0 (1.7\%), i- $\mathrm{C}_{18: 0}(0.8 \%), \mathrm{C}_{17: 0}$ cyclo $(0.8 \%)$, ai- $\mathrm{C}_{13: 0}(0.7 \%)$, $2 \mathrm{OH}-\mathrm{C}_{17: 0}(0.5 \%), \mathrm{C}_{14: 0}(0.4 \%), \mathrm{C}_{15: 1} w 6 c(0.4 \%), \mathrm{i}-\mathrm{C}_{17: 1} w 5 c(0.4 \%)$, $\mathrm{C}_{17: 0}(0.3 \%)$, ai- $\mathrm{C}_{16: 0}(0.3 \%), \mathrm{i}-3 \mathrm{OH}-\mathrm{C}_{16: 0}(0.2 \%)$ and ai- $\mathrm{C}_{14: 0}(0.2 \%)$. Mycolic acids were not detected. The $\mathrm{G}+\mathrm{C}$ content of the DNA was $70.4 \%$.

The $16 \mathrm{~S}$ rRNA gene-based tree, constructed using the neighborjoining method, showed that the strain $\mathrm{S} 16-07^{\mathrm{T}}$ formed a separate phyletic line from other representatives of the genus Streptomyces (Figure 2), notably from its closely related species S. smyrnaeus SM3501 ${ }^{\mathrm{T}}$ (97.7\%; 33/1414), S. abikoensis NBRC $13860^{\mathrm{T}}$ (97.6\%; 34/1403), S. thermocarboxydovorans NBRC $16324^{\mathrm{T}}$ (97.5\%; 35/1410) and S. lilacinus ISP $5254^{\mathrm{T}}$ (97.5\%; 35/1404). However, it was clear that strain $\mathrm{S} 16-07^{\mathrm{T}}$ represented a novel subline within the genus Streptomyces as its position in the tree was separated from these nearest phylogenetic neighbors. DNA-DNA hybridization tests were carried out between strain $S 16-07^{\mathrm{T}}$ and closely related strains selected on the basis of their $16 \mathrm{~S}$ rDNA sequence similarity. DNA-DNA relatedness values between strain $\mathrm{S} 16-07^{\mathrm{T}}$ and $S$. abikoensis $\mathrm{NBRC} 13860^{\mathrm{T}}(3.0 \%)$, S. thermocarboxydovorans NBRC $16324^{\mathrm{T}}(6.5 \%)$ and S. lilacinus ISP $5254^{\mathrm{T}}(13.8 \%)$ were all significantly lower than $70 \%$, the threshold value for the delineation of genomic species. ${ }^{37}$ On the basis of $16 \mathrm{~S}$ rRNA gene sequence data, DNA-DNA hybridization studies and biochemical properties, as well as physiological properties, it is proposed that strain $S 16-07^{\mathrm{T}}$ represents a novel species of genus Streptomyces, for which the name S. oryzae is proposed. The type strain is $\mathrm{S} 16-07^{\mathrm{T}}$.

\section{Description of $S$. oryzae sp. nov.}

S. oryzae (o.ry'zae. L. gen. n. oryzae of rice, referring to the rice plant where the strain was isolated) is aerobic, Gram-stain-positive, catalaseand oxidase-positive. The substrate mycelium does not fragment. The aerial hyphae bearing smooth-surfaced spores in hooks, open loops or primitive spiral spore chain (retinaculum apertum). White aerial mycelium and white to pale yellow substrate mycelium are produced on most media. A yellow soluble pigment is produced on ISP medium 2, ISP medium 3, ISP medium 4 and PDA. Good growth occurs on ISP medium 2, ISP medium 5 and Czapek's agar. Moderate growth is observed on ISP medium 3, ISP medium 4, nutrient agar and PDA. Melanin pigment is not produced. Growth occurs between 14 and $43^{\circ} \mathrm{C}$ and at $\mathrm{pH}$ 6.0-9.0. Uses adonitol, $\mathrm{L}(+)$ arabinose, $\mathrm{D}(+)$ cellobiose, $\mathrm{D}(-)$ fructose, $\mathrm{D}(+)$ galactose, $\mathrm{D}(+)$ glucose, glycerol, myo-inositol, beta-lactose, maltose, $\mathrm{D}(-)$ mannitol, $\mathrm{D}(-)$ rhamnose, raffinose, sucrose, $\mathrm{D}(+)$ trehalose and xylose as sole carbon sources, but not melibiose, $\mathrm{D}(-)$ sorbitol, sorbose and xylitol. The organism degrades casein, hypoxanthine, starch, tyrosine, xanthine and urea, but does not degrade adenine, cellulose, chitin and guanine. Tests for nitrate reductase and $\mathrm{H}_{2} \mathrm{~S}$ production are positive. LL-diaminopimelic acid is the diagnostic amino acid in the peptidoglycan and the muramic acid acyl type is acetyl. Galactose, glucose and ribose are found in whole-cell hydrolysates. The predominant menaquinones are MK-9 $\left(\mathrm{H}_{6}\right)$ and MK-9 $\left(\mathrm{H}_{8}\right)$. The major cellular fatty acids are ai- $\mathrm{C}_{15: 0}$, $\mathrm{i}-\mathrm{C}_{16: 0}$ and ai- $\mathrm{C}_{17: 0}$. The polar lipids include phosphatidylglycerol, diphosphatidylglycerol, hydroxy-phosphatidylethanolamine, hydroxyphosphatidylmonomethylethanolamine, phosphatidylethanolamine and phosphatidylinositol mannosides. Mycolic acids are absent. The DNA G+C content of the type strain is $70.4 \mathrm{~mol} \%$.

The type strain, S16-07 $7^{\mathrm{T}}\left(=\mathrm{BCC} 60400^{\mathrm{T}}=\mathrm{NBRC} 109761^{\mathrm{T}}\right)$, was isolated from stems of rice plant, $O$. sativa L., collected in Petchaburi province, Thailand.

\section{Accession code}

The DDBJ accession number for the 16S rRNA gene sequence of the strain $\mathrm{S} 16-07^{\mathrm{T}}$ is $\mathrm{AB} 894335$.

\section{ACKNOWLEDGEMENTS}

This research was supported by the Higher Education Research Promotion and National Research University Project of Thailand, Office of the Higher

Education Commission; Kitasato Institute for Life Sciences, Kitasato University, Japan; Faculty of Science, Kasetsart University, Thailand.

1 Waksman, S. A. \& Henrici, A. T. The nomenclature and classification of the Actinomycetes. J. Bacteriol. 46, 337-341 (1943).

2 Whitman, W. B. et al. Bergey's Manual of Systematic Bacteriology: Volume 5: The Actinobacteria 2nd edn (Springer, New York, 2012).

3 Euzéby, J. P. List of Prokaryotic names with Standing in Nomenclature (LPSN) (2014) http://www. bacterio.cict.fr/. Accessed 29 September 2014.

4 Kämpfer, P. in Genus I. Streptomyces Waksman and Henrici 1943, 339 emend. Witt and Stackebrandt 1990, 370 emend. Wellington, Stackebrandt, Sanders, Wolstrup and Jorgensen 1992, 159. Bergey's Manual of Systematic Bacteriology Vol. 5 (eds Goodfellow M. et al.) 1455-1767 (Springer, New York, 2012).

5 Mingma, R. et al. Sphaerisporangium rufum sp. nov., an endophytic actinomycete from roots of Oryza sativa L. Int. J. Syst. Evol. Microbiol. 64, 1077-1082 (2014).

6 Küster, E. \& Williams, S. T. Selection of media for isolation of streptomycetes. Nature 202, 928-929 (1964)

7 Umezawa, H., Tazaki, T. \& Fukuyama, S. An antiviral substance, abikoviromycin, produced by Streptomyces species. Jpn J. Med. 4, 331-346 (1951).

8 Kim, S. B., Falconer, C., Williams, E. \& Goodfellow, M. Streptomyces thermocarbox ydovorans sp. nov. and Streptomyces thermocarboxydus sp. nov., two moderately thermophilic carboxydotrophic species from soil. Int. J. Syst. Bacteriol. 48, 59-68 (1998).

9 Nakazawa, K., Tanabe, K., Shibata, M., Miyake, A. \& Takewaka, T. Studies on streptomycetes. Cladomycin, a new antibiotic produced by Streptomyces lilacinus nov. sp. J. Antibiot. 9, 81 (1956).

10 Tatar, D., Guven, K., Sproer, C., Klenk, H. P. \& Sahin, N. Streptomyces iconiensis sp. nov. and Streptomyces smyrnaeus sp. nov., two halotolerant actinomycetes isolated from a salt lake and saltern. Int. J. Syst. Evol. Microbiol. 64, 3126-3133 (2014)

11 Shirling, E. B. \& Gottlieb, D. Methods for characterization of Streptomyces species. Int. J. Syst. Bacteriol. 16, 313-340 (1966)

12 Waksman, S. A. The Actinomycetes. A Summary of Current Knowledge (Ronals Press, New York, 1967).

13 Jacobson, E., Grauville, W. C. \& Fogs, C. E. Color Harmony Manual 4th edn (Container Corporation of America, Chicago, 1958).

14 Humble, M. W., King, A. \& Phillips, I. API ZYM: a simple rapid system for the detection of bacterial enzymes. J. Clin. Pathol. 30, 275-277 (1977).

15 Gordon, R. E. \& Mihm, J. M. A comparative study of some strains received as nocardiae. J. Bacteriol. 73, 15-27 (1957).

16 Gordon, R. E., Barnett, D. A., Handerhan, J. E. \& Pang, C. H.-N. Nocardia coeliaca, Nocardia autotrophica, and the Nocardia strain. Int. J. Syst. Bacteriol. 24 54-63 (1974).

17 Becker, B., Lechevalier, M. P. \& Lechevalier, H. A. Chemical composition of cell-wall preparations from strains of various form-genera of aerobic actinomycetes. Appl. Microbiol. 13, 236-243 (1965)

18 Hasegawa, T., Takizawa, M. \& Tanida, S. A rapid analysis for chemical grouping of aerobic actinomycetes. J. Gen. Appl. Microbiol. 29, 319-322 (1983).

19 Lechevalier, H. A. \& Lechevalier, M. P. in Actinomycete Taxonomy (Society for Industrial Microbiology Special Publication no. 6). The Chemotaxonomy of Actinomycetes eds Dietz A., Thayer D. W.) 277-284 (VA: Society for Industrial Microbiology: Arlington, 1980).

20 Uchida, K. \& Aida, K. Acyl type of bacterial cell wall: its simple identification by a colorimetric method. J. Gen. Appl. Microbiol. 23, 249-260 (1977).

21 Minnikin, D. E., Patel, P. V., Alshamaony, L. \& Goodfellow, M. Polar lipid composition in the classification of Nocardia and related bacteria. Int. J. Syst. Bacteriol. 27, 104-117 (1977)

22 Tomiyasu, I. Mycolic acid composition and thermally adaptative changes in Nocardia asteroides. J. Bacteriol. 151, 828-837 (1982).

23 Collins, M. D., Pirouz, T., Goodfellow, M. \& Minnikin, D. E. Distribution of menaquinones in actinomycetes and corynebacteria. J. Gen. Microbiol. 100, 221-230 (1977).

24 Sasser, M. Identification of Bacteria by Gas Chromatography of Cellular Fatty Acids (MIDI Inc, Newark, DE, 1990).

25 Kieser, T., Bibb, M. J., Buttner, M. J., Chater, K. F. \& Hopwood, D. A. Practical Streptomyces Genetics (John Innes Foundation, Norwich, England, 2000).

$26 \mathrm{Kim}, \mathrm{O} . \mathrm{S}$, et al. Introducing EzTaxon-e: a prokaryotic 16S rRNA gene sequence database with phylotypes that represent uncultured species. Int. J. Syst. Evol. Microbiol. 62, 716-721 (2012).

27 Tamura, K. et al. MEGA5: molecular evolutionary genetics analysis using maximum likelihood, evolutionary distance, and maximum parsimony methods. Mol. Biol. Evol. 28, 2731-2739 (2011). 
28 Saitou, N. \& Nei, M. The neighbor-joining method: a new method for reconstructing phylogenetic trees. Mol. Biol. Evol. 4, 406-425 (1987).

29 Felsenstein, J. PHYLIP (Phylogenetic Inference Package) Version 3.5c (Department of Genetics, University of Washington, Seattle, WA, 1993).

30 Fitch, W. M. Toward defining the course of evolution: minimal change for a specific tree topology. Syst. Zool. 20, 406-416 (1971).

31 Jukes, T. H. \& Cantor, C. R in Evolution of Protein Molecules. Mammalian Protein Metabolism (ed Munro H. N.) 21-132 (Academic Press, New York, 1969).

32 Felsenstein, J. Confidence limits on phylogenies: an approach using the bootstrap. Evolution 39, 783-791 (1985).

33 Saito, H. \& Miura, K. I. Preparation of transforming deoxyribonucleic acid by phenol treatment. Biochim. Biophys. Acta 72, 619-629 (1963).
34 Ezaki, T., Hashimoto, Y. \& Yabuuchi, E. Fluorometric deoxyribonucleic aciddeoxyribonucleic acid hybridization in microdilution wells as an alternative to membrane filter hybridization in which radioisotopes are used to determine genetic relatedness among bacterial strains. Int. J. Syst. Bacteriol. 39, 224-229 (1989).

35 Tamaoka, J. \& Komagata, K. Determination of DNA base composition by reversed-phase high-performance liquid chromatography. FEMS Microbiol. Lett. 25, 125-128 (1984).

36 Lechevalier, M., Bievre, C. d. \& Lechevalier, H. A. Chemotaxonomy of aerobic Actinomycetes: phospholipid composition. Biochem. Syst. Ecol. 5, 249-260 (1977)

37 Wayne, L. G. et al. Report of the ad hoc committee on reconciliation of approaches to bacterial systematics. Int. J. Syst. Bacteriol. 37, 463-464 (1987).

Supplementary Information accompanies the paper on The Journal of Antibiotics website (http://www.nature.com/ja) 